\title{
PENGARUH PENGGANTIAN SEBAGIAN BUNGKIL KEDELAI DENGAN DAUN UBI KAYU YANG DIFERMENTASI DENGAN Aspergillus niger DALAM RANSUM TERHADAP PERFORMA AYAM BROILER
}

\author{
Yose Rizal, Dasril Tami, dan Vibriyani Rahmadian'
}

\begin{abstract}
INTISARI
Suatu percobaan telah dilakukan untuk menentukan pengaruh penggantian sebagian bungkil kedelai dengan daun ubi kayu yang difermentasi dengan Aspergillus niger (DUKF) dalam ransum terhadap performa ayam broiler. Sembilan puluh enam ekor ayam broiler campuran jantan dan betina umur tiga hari ditempatkan secara random dalam 24 buah kandang (empat ekor/kandang). Percobaan dirancang menggunakan rancangan acak lengkap dengan enam perlakuan dan empat ulangan. Perlakuan yaitu ransum yang mengandung $0,3,6,9,12$ dan $15 \%$ DUKF. Peubah yang diamati yaitu : konsumsi ransum, pertambahan berat badan, konversi ransum, berat hidup, persentase lemak abdomen dan persentase karkas ayam broiler. Hasil percobaan memperlihatkan bahwa konsumsi ransum, pertambahan berat badan, berat hidup, persentase lemak abdomen dan persentase karkas sangat nyata $(\mathrm{P}<0,01)$ dipengaruhi oleh peningkatan level DUKF dalam ransum, sedangkan konversi ransum tidak terpengaruh $(\mathrm{P}>0,05)$. Pemberian DUKF lebih dari $9 \%$ dalam ransum menurunkan konsumsi ransum, pertambahan berat badan, berat hidup, persentase lemak abdomen dan persentase karkas ayam broiler. Dengan demikian dapat disimpulkan bahwa DUKF hanya dapat dipakai sampai level $9 \%$ dalam ransum ayam broiler atau menggantikan $45 \%$ bungkil kedelai.
\end{abstract}

(Kata kunci: Daun ubi kayu fermentasi, Aspergillus niger, Bungkil kedelai, Ayam broiler, Performa).

Buletin Peternakan $29(3): 106-114,2005$

'Fakultas Peternakan, Universitas Andalas Padang. 


\title{
EFFECTS OF SUBSTITUTING SOYBEAN MEAL IN THE DIETS WITH Aspergillus niger-FERMENTED CASSAVA LEAVES ON THE PERFORMANCE OF BROILERS
}

\begin{abstract}
An experiment was conducted to determine the effects of subtitution of Aspergillus nigerfermented cassava leaves for some of soybean meal in the diets on the performance of broilers. Ninety six unsexed three day old broiler chicks were randomly allocated into 24 pens (four chicks/pen). This experiment was arranged in a completely randomized design with six dietary treatments $(0,3,6,9,12$, and $15 \%$ of Aspergillus niger-fermented cassava leaves in diets) and four replications. Measured variables were those of feed consumption, average body weight gain, feed conversion, live weight, abdominal fat percentage and carcass percentage. Results of experiment indicated that feed consumption, average body weight gain, live weight, abdominal fat percentage, and carcass percentage were highly affected $(\mathrm{P}<0.01)$ by levels of Aspergillus niger-fermented cassava leaves in the diets. Meanwhile, feed conversion was not influenced $(\mathrm{P}>0.05)$ by these dietary treatments. Increasing level of Aspergillus niger-fermented cassava leaves more than $9 \%$ in diets, recuced feed consumption, average body weight gain, live weight, abdominal fat percentage and carcass percentage of broilers. In conclusion, Aspergillus niger-fermented cassava leaves can be included up to $9 \%$ in diets for broilers ( $45 \%$ for replacement of soybean meal).
\end{abstract}

(Keywords : Fermented cassava leaves, Aspergillus niger, Soybean meal, Broiler, Performance).

\section{Pendahuluan}

Daun ubi kayu (DUK) merupakan limbah dari pemanenan umbi ubi kayu (Manihot utilissima, Pohl) yang jumlahnya cukup banyak di Sumatera Barat. Menurut BPS Sumbar (2000) luas lahan tanaman ubi kayu di Sumatera Barat adalah $7759 \mathrm{Ha}$. Tanaman ubi kayu ini menghasilkan DUK 715 ton per hektar setiap pemanenan umbi (Sudaryanto et al., 1982). Dengan demikian produksi DUK di Sumatera Barat tahun 2000 diperkirakan berkisar antara 54313136385 ton. Menurut Preston et al. (2000) dan Preston (2001) tanaman ubi kayu yang daunnya dipetik sekali 2 bulan mampu menghasilkan daun ubi kayu $80 \quad 120$ ton per hektar di Vietnam.

Daun ubi kayu ini mempunyai kandungan zat-zat makanan yang cukup baik dengan kandungan protein kasar yang tinggi, dan vitamin serta mineral yang cukup (Rogers and Millner, 1963; Ravindran and Ravindran, 1988; Aletor and Adeogun, 1995), sehingga berpotensi untrk dijadikan makanan ternak ruminansia dan monogastrik. Hasil penelitian Sudaryanto et al.
(1982) menunjukkan bahwa DUK mengandung protein kasar $21.45 \%$, serat kasar $25.71 \%$, lemak $9.72 \%, \mathrm{Ca} 0.72 \%$ dan P0.59\%. Menurut Mathius et al. (1983) komposisi kimia DUK yaitu: bahan kering $18.9 \%$, protein kasar $20.7 \%$, lemak kasar $9.35 \%$, BETN $41.3 \%$ dan abu $7.56 \%$, Daun ubi kayu juga mengandung $\mathrm{HCN}$ yang cukup tinggi, yaitu $560-620 \mathrm{ppm}$ pada yang muda dan $400-530$ ppm pada yang tua (Sudaryanto, 1986). Menurut Darma et al. (1994) DUK hanya bisa dipakai sampai $5 \%$ dalam ransum broiler. Kendala yang dihadapi yaitu DUK ini mengandung serat kasar dan $\mathrm{HCN}$ yang tinggi. Disamping itu daun ubi kayu juga mengandung tannin berkisar antara 30 $50 \mathrm{mg} / \mathrm{kg}$ (Ravindran, 1993) yang bisa mengganggu pencernaan dan penyerapan protein dan ketersediaan asam-asam amino esensil (Kumar and Sing, 1984). Hasil penelitian Rizal (1996) memperlihatkan bahwa DUK yang direbus selama 45 menit dengan tujuan untuk mengisolasi zat rutin yang dikandungnya dapat digunakan sampai $9 \%$ dalam ransum ayam broiler. Daun ubi kayu yang telah direbus selama 45 menit in kandungan HCNnya turun sampai $98.5 \%$ (Zulkardi, 1994). 
Jumlah pemberian DUK dalam ransum unggas masih sangat rendah jika ditujukan untuk menggantikan bungkil kedelai karena kandungan protein kasar DUK lebih rendah dari bungkil kedelai, sedangkan kandungan serat kasarnya jauh lebih tinggi. Untuk meningkatkan kandungan protein kasar dan menurunkan kandungan serat kasar ini diperlukan teknologi yang tepat. Salah satunya yaitu melalui proses fermentasi dengan menggunakan kapang. Pada proses fermentasi ini biasanya terjadi berbagai perubahan zat-zat organik yang terdapat dalam suatu bahan makanan seperti bertambahnya jumlah zat organik tertentu, hilangnya zat organik lainnya, atau zat organik tertentu menjadi lebih mudah dicerna (Winarno et al., 1980; Buckle et al., 1987).

Di antara kapang yang sering dipakai untuk fermentasi yaitu dari jenis Aspergillus niger. Darma et al. (1994) dan Bakrie et al. (1995) memperlihatkan bahwa terjadi peningkatan kandungan protein kasar DUK yang difermentasi dengan Aspergillus niger dan penurunan kandungan serat kasarnya. Hasil penelitian Wahyuni (2002) juga menunjukkan bahwa kandungan protein kasar DUK yang difermentasi dengan Aspergillus niger meningkat dari 18.88 menjadi $27.47 \%$. Akan tetapi belum ada informasi tentang pemakaian DUK yang difermentasi dengan Aspergillus niger ini yang ditujukan untuk mengganti sebagian dari bungkil kedelai dalam ransum ayam broiler.

Berdasarkan kenyataan ini maka dilakukan suatu penelitian dengan tujuan untuk mengetahui pengaruh penggantian sebagian bungkil kedelai dengan DUK yang difermentasi dengan Aspergillus niger dalam ransum terhadap performa ayam broiler.

\section{Materi dan Metode}

Suatu penelitian tentang pemakaian daun ubi kayu yang difermentasi dengan Aspergillus niger (DUKF) sebagai pengganti sebagian bungkil kedelai dalam ransum ayam broiler telah dilakukan pada kandang percobaan ternak unggas UPT Peternakan, Fakultas Peternakan Universitas Andalas dari tanggal 20 Desember 2003 sampai dengan 20 Februari 2004. Pada campuran jantan dan betina umur 3 hari dari strain Cobb. Ayam dipelihara dalam kandang ukuran $75 \times 60 \times 60 \mathrm{~cm}$ sebanyak 24 unit dengan jumlah 4 ekor per unit kandang. Kandang ini dilengkapi dengan tempat makan dan tempat minum serta lampu pijar 60 watt sebanyak 12 buah ( 1 buah untuk 2 unit kandang) sebagai sumber cahaya dan untuk pemanasan. Peralatan untuk menimbang ayam digunakan timbangan teknis berkapasitas 2610 gram.

Bahan-bahan pakan sebagai campuran ransum yang dipakai yaitu : jagung giling, dedak padi halus, bungkil kedelai, tepung ikan, bungkil kelapa, tepung DUKF, tepung tulang dan minyak kelapa. Ransum disusun iso protein $(23,0 \%)$ dan iso energi (3050 $\mathrm{Kkal} / \mathrm{Kg}$ ransum). Kandungan zat-zat makanan dan energi termetabolis bahanbahan pakan penyusun ransum penelitian ditampilkan pada Tabel I, susunan bahan pakan penyusun ransum penelitian pada Tabel 2, dan kandungan gizi serta energi termetabolis (ME) ransum penelitian pada Tabel 3 .

Rancangan yang digunakan pada penelitian ini yaitu rancangan acak lengkap (RAL) yang terdiri atas 6 perlakuan dan 4 ulangan.

Keenam macam perlakuan tersebut adalah:

$$
\begin{aligned}
& \mathrm{A}=\text { ransum dengan } 0 \% \text { DUKF } \\
& \mathrm{B}=\text { ransum dengan } 3 \% \text { DUKF } \\
& \mathrm{C}=\text { ransum dengan } 6 \% \text { DUKF } \\
& \mathrm{D}=\text { ransum dengan } 9 \% \text { DUKF } \\
& \mathrm{E}=\text { ransum dengan } 12 \% \text { DUKF } \\
& \mathrm{F}=\text { ransum dengan } 15 \% \text { DUKF }
\end{aligned}
$$

Anak ayam ditempatkan dalam 24 unit kandang sebanyak 4 ekor setiap unit kandang dengan rataan berat badan awal yang hampir sama untuk setiap unit kandang. Perlakuan ditempatkan secara acak pada masing-masing unit kandang. Sebelum anak ayam ditempatkan dalam kandang, kandang tersebut terlebih dahulu. disucihamakan dengan desinfektan merek Rodalon. Ransum dan air minum diberikan pada ternak ad-libitum. Pemberian ransum dilakukan tiga kali sehari yaitu : pukul 8:00, 12:00 dan 16:00. Air minum diganti setiap hari yang dilakukan pada pagi hari. Cahaya diberikan secara kontinyu selama percobaan. Percobaan ini dilakukan selama empat minggu. 
Tabel 1. Kandungan gizi dan energi termetabolis bahan pakan penyusun ransum (sebagaimana diberikan) ${ }^{1}$ (Nutrient content and metabolizable energy of feeds in diet (as fed) ${ }^{l}$ )

\begin{tabular}{|c|c|c|c|c|c|c|}
\hline $\begin{array}{l}\text { Bahan pakan } \\
\text { (Feed) }\end{array}$ & $\begin{array}{l}\text { Protein kasar } \\
\text { (\%) (Crude } \\
\text { protein (\%)) }\end{array}$ & 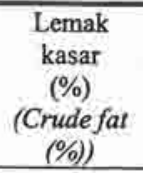 & $\begin{array}{l}\text { Serat kasar } \\
(\%)(C r u d e \\
\text { fiber }(\%))\end{array}$ & $\begin{array}{l}\text { Ca (\%) } \\
\text { (Calcium } \\
(\%))\end{array}$ & $\begin{array}{c}\mathrm{P}(\%) \\
\text { (Phosphor } \\
(\%))\end{array}$ & $\begin{array}{c}\mathrm{ME}^{3}(\mathrm{kkal} / \mathrm{Kg}) \\
\text { (Metabolizable } \\
\text { energy } \\
\text { (kcal/Kg) }\end{array}$ \\
\hline $\begin{array}{l}\text { Jagung kuning } \\
\text { (Yellow corn) } \\
\text { Dedak padi }\end{array}$ & 10,42 & 2,66 & 1,84 & 0,06 & 0,37 & 3370 \\
\hline (Rice bran) & II,19 & 11,22 & 13,85 & 0,07 & 0,70 & 1630 \\
\hline $\begin{array}{l}\text { (Soybean meal) } \\
\text { DUKF }^{2} \quad \text { (Fermented }\end{array}$ & 43,18 & 1,67 & 4,66 & 0,27 & 0,60 & 2240 \\
\hline $\begin{array}{l}\text { cassava leaves) } \\
\text { Tepung ikan }\end{array}$ & 30,04 & 6,25 & 27,61 & 0,25 & 0,34 & $3020^{4}$ \\
\hline $\begin{array}{l}\text { (Fish meal) } \\
\text { Bungkil kelapa }\end{array}$ & 58,59 & 3,50 & 1,99 & 3,41 & 1,31 & 3080 \\
\hline $\begin{array}{l}\text { (Coconut meal) } \\
\text { Tepung tulang }\end{array}$ & 20,64 & 7,23 & 11,24 & 0,35 & 0,49 & 1540 \\
\hline $\begin{array}{l}\text { (Bone meal) } \\
\text { Minyak kelapa }\end{array}$ & - & - & - & 24,16 & 11,99 & - \\
\hline (Coconut oil) & - & 100 & - & - & - & 8600 \\
\hline $\begin{array}{l}\text { Hasil analisis di Lab. G } \\
\text { Animal Science Andala } \\
\text { Hasil analisis di Labo } \\
\text { Technology and Industr } \\
\text { Scott, et al. (1982) } \\
\text { Rumus NRC (1984) }\end{array}$ & $\begin{array}{l}\text { Ruminansia F } \\
\text { Iniversity (2003 } \\
\text { torium Teknol } \\
\text { aboratory Fac } \\
\text { C Formulation }\end{array}$ & $\begin{array}{l}\text { as Peternal } \\
\text { Industri P } \\
\text { of Animal. } \\
\text { 4)). }\end{array}$ & $\begin{array}{l}\text { Fakultas } \mathrm{P} \\
\text { ce Andalas }\end{array}$ & $\begin{array}{l}\text { alyzed at } \\
\text { akan Un } \\
\text { rsity (20 }\end{array}$ & (2003) ( & $\begin{array}{l}\text { tory Faculty of } \\
\text { tyzed at Feed }\end{array}$ \\
\hline
\end{tabular}

Peubah yang diamati pada percobaan ini yaitu konsumsi ransum selama penelitian (gram/ekor), pertambahan berat badan selama penelitian (gram/ekor), konversi ransum, berat hidup (gram/ekor), persentase lemak abdomen dan persentase karkas. Konsumsi ransum diukur dari konsumsi setiap minggu selama 4 minggu penelitian dan konsumsi tiap minggu dijumlahkan untuk mendapatkan konsumsi ransum selama penelitian lalu dibagi dengan jumlah ayam per unit percobaan untuk mendapatkan konsumsi ransum per ekor selama penelitian. Pertambahan berat badan diukur setiap minggu selama 4 minggu penelitian dan untuk mendapatkan pertambahan berat badan per ekor selama penelitian pertambahan berat badan setiap minggu dijumlahkan lalu dibagi dengan jumlah ayam per unit percobaan. Konversi ransum dihitung dari membagi antara konsumsi ransum per ekor selama penelitian dengan pertambahan berat badan per ekor selama penelitian. Berat hidup (gram/ekor) diperoleh dengan menimbang seluruh ayam pada masing-masing unit percobaan pada akhir penelitian dan dibagi dengan jumlah ayam pada setiap unit percobaan. Persentase lemak abdomen dihitung dari berat lemak abdomen dibagi dengan berat karkas dan dikali $100 \%$. Persentase karkas dihitung dari berat karkas dibagi dengan berat hidup ayam dan dikali $100 \%$. Berat karkas ayam yaitu berat ayam yang telah dipotong dan dibuang kepala sampai ke leher, sayap, kaki, bulu dan jeroan, kecuali paruparu dan ginjal (Nesheim et al., 1979). Untuk mendapatkan persentase lemak abdomen dan persentase karkas ini hanya menggunakan satu ekor ayam per unit percobaan dengan memilih ayam yang mendekati berat rata-rata dalam setiap unit percobaan untuk dipotong.

Semua data yang diperoleh dianalisis dengan analisis keragaman dari Rancangan Acak Lengkap dengan model rancangannya menurut Petersen (1985) yaitu:

$$
\mathrm{Yij}=\mathrm{u}+\mathrm{Tj}+\mathrm{Eij}
$$


Tabel 2. Susunan bahan pakan ransum percobaan $(\%)^{1}$ (Feed formulation in experimental diets $(\%)^{l}$ )

\begin{tabular}{|c|c|c|c|c|c|c|}
\hline \multirow[b]{2}{*}{ Bahan Pakan (Feed) } & \multicolumn{6}{|c|}{ Ransum percobaan (Experimental diet) } \\
\hline & A & B & C & D & E & $\mathrm{F}$ \\
\hline $\begin{array}{l}\text { Jagung kuning } \\
\text { (Yellow corn) }\end{array}$ & & & & & & \\
\hline $\begin{array}{l}\text { (Yellow corn) } \\
\text { Dedak padi (Rice bran) }\end{array}$ & $\begin{array}{c}54,50 \\
6,50\end{array}$ & $\begin{array}{c}54,50 \\
6,50\end{array}$ & $\begin{array}{r}53,00 \\
700\end{array}$ & 53,00 & $\begin{array}{c}53,00 \\
7,00\end{array}$ & $\begin{array}{c}53,00 \\
6,00\end{array}$ \\
\hline Bungkil kedelai & & & & & & \\
\hline $\begin{array}{l}\text { (Soybean meal) } \\
\text { DUKF (Fermented }\end{array}$ & 20,00 & 17,00 & 14,00 & 11,00 & 8,00 & 5,00 \\
\hline $\begin{array}{l}\text { cassava leaves) } \\
\text { Tepung ikan }\end{array}$ & 0,00 & 3,00 & 6,00 & 9,00 & 12,00 & 15,00 \\
\hline $\begin{array}{l}\text { (Fish meal) } \\
\text { Bungkil kelapa }\end{array}$ & 13,00 & 13,50 & 14,50 & 15,00 & 15,50 & 16,50 \\
\hline $\begin{array}{l}\text { (Coconut meal) } \\
\text { Tepung tulang }\end{array}$ & 2,00 & 2,00 & 2,00 & 2,00 & 2,00 & 2,00 \\
\hline $\begin{array}{l}\text { (Bone meal) } \\
\text { Minyak kelapa }\end{array}$ & 1,50 & 1,50 & 1,50 & 1,50 & 1,50 & 1,50 \\
\hline (Coconut oil) & 2,50 & 2,00 & 2,00 & 1,50 & 1,00 & 1,00 \\
\hline Total & 100,00 & 100,00 & 100,00 & 100,00 & 100,00 & 100,00 \\
\hline
\end{tabular}

Disusun berdasarkan Tabel 1. (Formulated based on Table 1).

Tabel 3. Kandungan gizi dan energi termetabolis ransum percobaan ${ }^{1}$ (Nutrient content and metabolizable energy of experimental diets ${ }^{1}$ )

\begin{tabular}{|c|c|c|c|c|c|c|}
\hline \multirow{2}{*}{ Komponen (Component) } & \multicolumn{6}{|c|}{ Ransum percobaan (Experimental diet) } \\
\hline & A & B & $\mathrm{C}$ & $\mathrm{D}$ & $\mathrm{E}$ & F \\
\hline Protein kasar (\%) & & & & & & \\
\hline $\begin{array}{l}\text { (Crude protein (\%)) } \\
\text { Lemak kasar (\%) }\end{array}$ & 23,07 & 22,97 & 23,06 & 22,96 & 22,86 & 22,94 \\
\hline (Crude fat (\%)) & 5,61 & 5,27 & 5,46 & 5,11 & 4,76 & 4,83 \\
\hline Serat kasar (\%) & & & & & & \\
\hline (Crude fiber (\%)) & 3,32 & 4,02 & 4,77 & 5,47 & 6,16 & 6,73 \\
\hline $\begin{array}{l}\mathrm{Ca}(\%)(\text { Calcium }(\%)) \\
\text { P total }(\%)\end{array}$ & 0,90 & 0,92 & 0,95 & 0,97 & 0,99 & 1,02 \\
\hline $\begin{array}{l}\text { (Phosphor total (\%)) } \\
\text { ME (Kkal/Kg) Metab }\end{array}$ & 0,73 & 0,73 & 0,73 & 0,73 & 0,73 & 0,73 \\
\hline $\begin{array}{l}\text { ME (Kka/Kg) (Metabollza } \\
\text { energy (Kcal/Kg)) }\end{array}$ & 3037 & 3033 & 3044 & 3040 & 3036 & 3074 \\
\hline
\end{tabular}


Perbedaan secara statistik antar rataan perlakuan diuji lanjut dengan Duncan Multiple Range Test (DMRT).

\section{Hasil dan Pembahasan}

Pengaruh perlakuan terhadap rataan konsumsi ransum, pertambahan bobot badan, konversi ransum, berat hidup, persentase lemak abdomen dan persentase karkas disajikan pada Tabel 4. Hasil analisis statistik menunjukkan bahwa perlakuan memberikan pengaruh yang sangat nyata $(\mathrm{P}<0.01)$ terhadap konsumsi ransum ayam broiler. Semakin tinggi DUKF dalam ransum, semakin rendah jumlah ransum yang dikonsumsi.

Pemakaian DUKF sampai $9 \%$ dalam ransum tidak mempengaruhi konsumsi ransum, tetapi jika pemakaiannya ditingkatkan menjadi 12 dan $15 \%$ dalam ransum terjadi penurunan konsumsi ransum. Terjadinya penurunan konsumsi ransum ini dapat disebab oleh peningkatan kandungan serat kasar dalam ransum. Serat kasar yang tinggi dapat menimbulkan rasa kenyang pada ayam broiler karena serat ini bersifat "bulky" dan voluminous, sehingga menimbulkan tekanan pada lambung ayam yang dapat menyebabkan rasa kenyang (Scott, et al., 1982; Parakkasi, 1999). Makanan yang mengandung serat kasar tinggi juga kurang palatabel dibandingkan dengan makanan yang rendah serat, sehingga terjadi penurunan konsumsi ransum. Penurunan konsumsi ransum dapat pula disebabkan oleh ketidakseimbangan asam-asam amino dalam ransum (Forbes, 1986) karena semakin tinggi DUKF dalam ransum semakin berkurang pemakaian bungkil kedelai. Hal ini menyebabkan kandungan asam-asam amino dalam ransum menjadi tidak seimbang karena kandungan asam-asam amino bungkil kedelai lebih tinggi dari pada DUKF.

Pertambahan berat badan ayam broiler sangat

Tabel 4. Pengaruh percobaan terhadap performa ayam broiler selama percobaan

(Effects of experimental diets on the performance of broilers during experiment)

\begin{tabular}{|c|c|c|c|c|c|c|c|}
\hline \multirow[b]{2}{*}{$\begin{array}{l}\text { Performa } \\
\text { (Performance) }\end{array}$} & \multicolumn{6}{|c|}{ Ransum percobaan (Experimental dets) } & \multirow[b]{2}{*}{$\mathrm{SE}^{*}$} \\
\hline & A & B & C & $\mathrm{D}$ & $\mathrm{E}$ & F & \\
\hline $\begin{array}{l}\text { Konsumsi ransum } \\
\text { (g/ekor) (Feed } \\
\text { consumption } \\
\text { (g/head)) } \\
\text { Pertambahan berat } \\
\text { badan (g/ekor) }\end{array}$ & $1655,53^{\mathrm{a}}$ & $1725,22^{\mathrm{a}}$ & $1670,97^{\mathrm{a}}$ & $644,23^{a}$ & $1377,56^{\mathrm{b}}$ & $1218,16^{b}$ & 57,73 \\
\hline $\begin{array}{l}\text { (Body weight gain } \\
\text { (g/head)) } \\
\text { Konversi ransum }\end{array}$ & $787,52^{\mathrm{a}}$ & $846,12^{2}$ & $788,10^{\mathrm{a}}$ & $73,58^{2}$ & $636,65^{b}$ & $566,69^{b}$ & 26,53 \\
\hline $\begin{array}{l}\text { (Feed conversion) } \\
\text { Berat hidup }\end{array}$ & 2,11 & 2,04 & 2,12 & 2,13 & 2,17 & 2,18 & 0,11 \\
\hline $\begin{array}{l}\text { (g/ekor) (Live } \\
\text { weight (g/head) } \\
\text { Persentase lemak }\end{array}$ & $846,63^{\mathrm{a}}$ & $910,13^{\mathrm{a}}$ & $848,75^{\mathrm{a}}$ & $834,40^{\mathrm{a}}$ & $700,47^{b}$ & $623,97^{b}$ & 31,65 \\
\hline $\begin{array}{l}\text { Abdomen } \\
\text { (Abdominal fat } \\
\text { percentage) } \\
\text { Persentase karkas } \\
\text { (Carcass } \\
\text { percentage) }\end{array}$ & $1,23^{\mathrm{a}}$ & $1,29^{\mathrm{a}}$ & $1,26^{\mathrm{a}}$ & $1,25^{\mathrm{a}}$ & $1,02^{\mathrm{b}}$ & $0,99^{\mathrm{b}}$ & 0,05 \\
\hline ,b,c Rataan denga & rskrip y & erbeda & aris yan & na menu & kkan ber & a nyata & $\frac{1,40}{60.05)}$ \\
\hline
\end{tabular}


nyata $(\mathrm{P}<0.01)$ dipengaruhi oleh perlakuan. Semakin tinggi level DUKF dalam ransum semakin turun pertambahan berat badan. Dari hasil penelitian ini terjadi penurunan pertambahan berat badan ayam broiler jika pemakaian DUKF ditingkatkan dari 9 menjadi 12 dan $15 \%$. Dengan demikian pemakaian DUKF sampai $9 \%$ dalam ransum tidak mempengaruhi pertambahan berat badan pada ayam broiler. Terjadinya penurunan pertambahan berat badan ini disebabkan oleh terjadinya penurunan konsumsi ransum pada level DUKF yang lebih dari $9 \%$. Hal ini sesuai dengan pendapat Siregar et al. (1980) bahwa jumlah ransum yang dikonsumsi menentukan terhadap pertambahan berat badan. Peningkatan pemakaian DUKF juga mengurangi pemakaian bungkil kedelai. Dengan demikian bisa terjadi ketidakseimbangan asam-asam amino esensil dalam ransum karena kandungan asam amino esensil pada DUKF lebih rendah dari bungkil kedelai. Menurut Siregar et al. (1980) kekurangan asam amino esensil dapat menurunkan pertambahan berat badan. Ditambahkan pula oleh Muindi and Hanssen (1981) bahwa bahan pakan yang difermentasi dengan Trichoderma harzianum memiliki $30 \%$ NPN dari total protein kasar. Non protein nitrogen ini tidak dapat dimanfaatkan oleh unggas untuk pertumbuhannya (Scott et al., 1982). Selain dari itu, berkemungkinan DUKF masih mengandung tannin. Menurut Kumar dan Sing (1984) tannin ini dapat menggangu pencernaan protein dan penyerapan asam-asam amino oleh usus halus, sehingga pertambahan berat badan ayam broiler terganggu.

Konversi ransum tidak dipengaruhi $(\mathrm{P}>0.05)$ oleh perlakuan. Peningkatan level pemakaian DUKF untuk menggantikan bungkil kedelai sampai $15 \%$ tidak menaikkan angka konversi ransum atau menurunkan efisiensi penggunaan ransum. Hasil penelitian ini menunjukkan bahwa penurunan pertambahan berat badan ayam broiler pada penelitian ini proporsional dengan penurunan konsumsi ransum, sehingga angka konversi ransum tidak berbeda.

Berat hidup ayam broiler sangat nyata $(\mathrm{P}<0.01)$ dipengaruhi oleh perlakuan. Berat hidup semakin turun dengan meningkatnya pemakaian DUKF dalam ransum. Pemakaian DUKF sampai $9 \%$ dalam ransum tidak menurunkan berat hidup, tetapi jika pemakaian ditingkatkan menjadi 12 dan $15 \%$, maka terjadi penurunan berat hidup ayam broiler. Berat hidup ternak unggas sangat tergantung kepada jumlah dan kualitas ransum yang dikonsumsi (Wahju, 1992). Pada penelitian ini jumlah ransum yang dikonsumsi makin turun, demikian pula dengan kualitasnya yang ditandai dengan peningkatan serat kasar dalam ransum dengan meningkatnya pemakaian DUKF, sehingga terjadi penurunan berat hidup. Serat kasar yang tinggi dalam ransum juga bisa membawa zat-zat makanan seperti protein/asam-asam amino, vitamin dan mineral keluar bersama feses, akibatnya retensi protein dalam tubuh bisa turun, sehingga berat hidup ayam jadi turun.

Perlakuan sangat nyata $(\mathrm{P}<0.01)$ mempengaruhi persentase lemak abdomen ayam broiler. Peningkatan level pemakaian DUKF dalam ransum menurunkan persentase lemak abdomen. Pemakai DUKF sampai level $9 \%$ tidak menurunkan persentase lemak abdomen, tetapi jika level ini ditingkatkan menjadi 12 sampai $15 \%$ dalam ransum mengakibatkan penurunan persentase lemak abdomen. Terjadinya penurunan persentase lemak abdomen ini dapat disebabkan kandungan serat kasar yang semakin tinggi pada ransum yang mengandung DUKF yang semakin tinggi. Seperti diketahui serat kasar merupakan zat makanan yang tidak dapat dicerna oleh ternak unggas karena unggas tidak menghasilkan enzim yang mampu mencerna serat kasar (Leeson and Summers, 2001). Dengan demikian ayam broiler akan kekurangan energi untuk dapat disimpan dalam bentuk lemak, sehingga tidak terjadi penumpukan lemak dalam rongga abdomen ayam broiler.

Persentase karkas ayam broiler sangat nyata $(\mathrm{P}<0.01)$ dipengaruhi oleh perlakuan. Peningkatan pemakaian DUKF dalam ransum menurunkan persentase karkas. Pemakaian DUKF sampai $9 \%$ tidak menurunkan persentase karkas ayam broiler, tetapi jika pemakaiannya ditingkatkan menjadi 12 dan $15 \%$, maka terjadi penurunan persentase karkas ayam broiler tersebut. Dengan demikian DUKF hanya dapat dipakai sampai $9 \%$ dalam ransum ayam broiler tanpa menurunkan persentase karkas 


\section{Kesimpulan}

Pemakaian daun ubi kayu yang difermentasi dengan Aspergillus niger atau DUKF melebihi $9 \%$ dalam ransum menurunkan konsumsi ransum, pertambahan berat badan, berat hidup, persentase lemak abdomen dan persentase karkas ayam broiler, tetapi konversi ransum tidak terpengaruh. Dengan demikian DUKF hanya bisa dipakai sampai level $9 \%$ dalam ransum ayam broiler.

\section{Daftar Pustaka}

Aletor, V. A. and O. A. Adeogun. 1995. Nutrients and Antinutrient Components of Some Tropical Leafy Vegetables. Food Chem., 54:375-379.

Bakrie, B., J. Hendra and A. Nazar. 1995. Effects of Using Different Technique in Bioprocess on the Nutritive Value of Cassava Leaves. Proceedings on XI National Biology Seminar. University of Indonesia, Jakarta.

BPS Sumbar. 2000. Sumatera Barat dalam Angka. Badan Pusat Statistik Sumatera Barat, Padang.

Buckle, K. A., R. A. Edwards, D. H. Fleet dan M. Wootton. 1987. Ilmu Pangan. Terjemahan oleh Andiono dan H. Purnomo. Universitas Indonesia Press, Jakarta.

Darma, J., T. Purwadaria, T. Haryati, A. P. Sinurat dan R. Dharsana. 1994. Upgrading the Nutritional Value of Cassava Leaves Through Fungal Biotechnology. Research Institute for Animal Production Report for FAO/ANBAPH, Ciawi, Bogor.

Forbes, J. M. 1986. The Voluntary Food Intake of Farm Animals. Butterworth \& Co., London.

Kumar, R. and M. Singh. 1984. Tannins, Their Adverse Role in Ruminant Nutrition. J. Agric. Food Chem., 32: 447-453.

Leeson, S. and J. D. Summers. 2001. Nutrition of the Chicken. Forth Ed. University Books, Guelph, Canada.

Mathius, W., A. Djajanegara dan M. Rangkuti 1983. Pengaruh Penambahan Daun
Singkong dalam Ransum Domba. IImu dan Peternakan, BPT Ciawi, Bogor.

Muindi, P. J. and J. F. Hanssen. 1981. Protein Enrichment of Cassava Root Meal by Trichoderma Harzianum for Animal Feed. J. Sci. Food and Agric. 32 : 655661.

Nesheim, M. C., R. E. Austic, and L. E. Card. 1979. Poultry Production. Twelfth Ed. Lea \& Febiger, Philadelphia.

NRC, 1984. Nutrient Requirements of Poultry. Eighth Revised Ed. National Academy of Science, Washington DC.

Parakkasi, A. 1999. Ilmu Nutrisi dan Makanan Ternak Ruminansia. UI Press, Jakarta.

Petersen, R. G. 1985. Design and Analysis of Experiments. Marcell Dekker, Inc., New York.

Preston, T. R., L. Rodriguez and B. Khieu. 2000. Association of Cassava and Legume Trees as Perennial Forage Crops for Livestock. Workshop-seminar "Marking Better use of Local Feed Resources" January 2000. SAREC-UAF. UAF Ho Chi Minh City, Vietnam.

Preston, T. R. 2001. Potential of Cassava in Integrated Farming Systems. International Workshop Current Research and Development on Use of Cassava as Animal Feeds, Khon Kaen, Thailand July 23-24, 2001.

Ravindran, V. and G. Ravindran. 1988. Changes in the Nutritional Composition of Cassava (Manihot esculenta, Crantz.) Leaves Maturity. Food Chemistry (27): 299-309.

Ravindran, V, 1993. Cassava Leaves as Animal Feed : Potential and Limitations. J. Sci. FoodAgric. $61: 141-150$.

Rizal, Y. 1996. Penggunaan Daun Singkong Limbah Isolasi Rutin dalam Ransum Ayam Petelur dan Broiler. Jurnal Peternakan dan Lingkungan, Vol. 2 No. 01, Padang.

Rogers, D. J. and M. Milner. 1963. Econ. Bot. 17 : 211. Rep. Rothamsted Exp. Sta. Harpenden, 1957,pp: 101.

Scott, M. L., M. C. Nesheim, and R. J. Young. 1982. Nutrition of the Chicken. Third Edition. M. L. Scott \& Associates, Ithaca, New York. 
Siregar, A. P., M. Sabrani dan P. Suroprawiro. 1980. Teknik Beternak Ayam Pedaging di Indonesia. Margie Group, Jakarta.

Sudaryanto, B., I. N. Rangkuti dan A. Prabowo. 1982. Penggunaan Tepung Daun Singkong dalam Ransum Babi. Ilmu dan Peternakan, BPT Ciawi, Bogor.

Sudaryanto, B. 1986. Daun Singkong Sebagai Sumber Pakan Ternak. Poultry Indonesia, Vol. VII, No. 75, Jakarta.

Wahju, J. 1992. Ilmu Nutrisi Unggas. Cetakan Ketiga. Gadjah Mada University Press, Yogyakarta.
Wahyuni, R. 2002. Pengaruh Lama Perebusan dan Level Inokulum Aspergillus niger terhadap Kadar Bahan Kering, Protein Kasar, HCN dan Nilai pH Daun Ubi Kayu (Manihot utilissima) Fermentasi.

Winarno, F. G., S. Fardiaz dan D. Fardiaz. 1980. Pengantar Teknologi Pangan. PT. Gramedia, Jakarta.

Zulkardi. 1994. Pemanfaatan Daun Ubi Kayu Limbah Isolasi Rutin dalam Ransum Ayam Petelur pada Masa Produksi. Skripsi Sarjana. Fakultas Peternakan UNAND, Padang. 